\title{
Ahn Jung-Geun's on Peace in East Asia a Way to Resolve Northeast Asian Nations' Historical Conflicts
}

\author{
Yoo Song Lee
}

\begin{abstract}
A century has passed since the death of Korea's Hero, Ahn Jung Geun. There are several organizations, institutions founded so as to not only cherish the deceased man but also reevaluate his works. Especially his ideas about East Asian peace which are evident in his writing On Peace in East Asia are hotly debated among scholars. This author also examines Ahn's On Peace in East Asia as well, but with different approach. Rather than assessing the work in the context of economy or politics, the author tried to apply Ahn's thoughts in a historical context. Having realized that the ongoing historical conflicts between Northeast Asia nations, Korea, China, and Japan result in serious diplomatic disputes, the author sought ways to adapt the fundamental concepts of On Peace in East Asia to the resolution of these conflicts. The contents of the paper include the basic ideas of On Peace in East Asia, significant historical conflicts taking place in Northeast Asia, and the possible solutions to resolve the problems.
\end{abstract}

Index Terms-Ahn Jung-Geun, on peace in East Asia, historical conflicts, history textbook, Hallyu

\section{INTRODUCTION}

Originally well-known for his assassination of Ito Hirobumi, the symbol of Japan imperialism, at Haerbin station, Ahn Jung-Geun sparked a renewed discussion among scholars in $21^{\text {st }}$ century with his book, on Peace in East Asia.[1] As the title implies, Ahn's on Peace in East Asia contends that contemporary East Asia - particularly Korea, China, and Japan - should stand against Western power as union.[1], [2] He intended to categorize it into five parts, but his death sentence preceded the completion of his writing, so only the front parts remain.[2] However, there are other documents that give us a hint about his philosophy regarding East Asia peace. Among his ideas, the suggestion of East Asia Peace Conference has been profoundly examined by experts who came up with similar designs, such as Asia Monetary Cooperation, East Asia peace system, and multilateral organization. Unlike these existing research that interpreted on Peace in East Asia in either political or economic aspect, this paper intends to approach it in a historical context and Fig. out possible ways to work out ongoing historical disputes among Korea, China, and Japan.

It is not an exaggerated saying that historical conflicts among these countries hinder the ultimate peace of East Asia. As to the causes of Northeast Asian nations' historical disputes, they include nations' distortion of history, nationalism, remains of Japanese imperialism, etc.[3] Since

Manuscript received July 25, 2013; revised September 29, 2013.

Yoo Song Lee is with the Hankuk Academy of Foreign Studies (e-mail: leeyoosong@gmail.com). historical conflicts are often associated with territorial disputes, they tend to result in more serious political and diplomatic clashes.[4], [5] As a matter of fact, in 2012 when historical conflict between Japan and China over Senkaku (or Diaoyudao) Islands hit the peak, both nations sent approximately 60 fleets near the islands and Chinese anti-Japan hostility escalated to the point that the safety of Japanese in mainland China was threatened.[5] Likewise, it seems important to resolve historical conflicts between Northeast Asia countries that not only affect economical national interest but also bring about political, diplomatic troubles.[5] As one way to solve the matter, this paper suggests the adaption of Ahn Jung-Geun's on Peace in East Asia.

Ahn's on Peace in East Asia has much to provide in $21^{\text {st }}$ century. In particular, Ahn stresses the need for Korea, Japan, and China to cooperate, unite, and collaborate so as to walk the road of common prosperity.[5], [6] By examining Ahn's piece of work in depth, this paper seeks ways to adapt this spirit of collaboration in overcoming historical conflicts of current Northeast Asia. Granted, historical conflicts and ill feelings that lasted for several decades cannot be alleviated at once, but I hope this paper can be of help in overcoming Northeast Asia's historical conflicts through On Peace in East Asia.

\section{Ahn Jung-Geun's ON PEACE IN EAST ASIA}

To truly understand the work on Peace in East Asia, it is crucial to examine the author, Ahn Jung-Geun. Ahn was a Korean independence activist during Japanese Occupation. $\mathrm{He}$ is famous for assassinating Ito Hirobumi, the first Resident-General of Korea, who was the symbol of Japanese imperialism and the brutal suppression carried out against Koreans. On the charge of killing Ito Hirobumi, Ahn was sentenced to death. It was during this period he was imprisoned that he began to write on Peace in East Asia. [6]

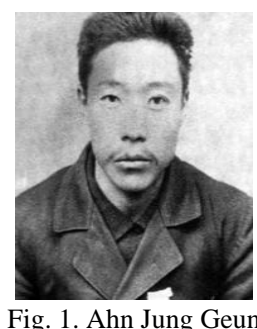

In on Peace in East Asia, he argued the need of strongly bound East Asian Community, especially that of Korea, China, and Japan. Since his sentence was carried out before the completion of on Peace in East Asia, only some parts of it 
remain. His remaining ideas, fortunately, are revealed in the records of his interrogation.[6] Ahn Jung-Geun proposes mainly four ways to bring peace in East Asia - earning international credit, organizing the East Asia Peace Conference, building the joint bank that issues common currency, and getting support from other nations. [6], [7] Such system is often compared to that of European Union and whether it is applicable in modern society has been hotly debated among scholars.

Besides the idea of organizing Peace Conference, Ahn Jung-Geun also lauded Japan's victory over Russia during Russo-Japan war, which he likened to the "white versus yellow war."'[7] He explained that it was the result of cooperation among Korea, China, and Japan. (Of course he later denounces Japan for abandoning its words about Korea's independence, ruthlessly exploiting Korea's resources, and suppressing Koreans.)[7] Even though this view may seem xenophobic and racially discriminating, it should be taken into consideration that until then, Korea had been a Confucian society that strictly followed traditions and conservative norms, and that it took the approaching Western imperialism (especially Russia) as a serious threat to society.

From these ideals of Ahn Jung-Geun's on Peace in East Asia, this paper aims to draw possible ways to resolve ongoing historical conflicts among Northeast Asian countries.

\section{NORTHEAST ASIAN NATIONS' HistoricAl CONFLICTS}

This paper defines historical conflict as a dispute between nations that has its root in history. Northeast Asian nations Korea, China, and Japan - have been ceaselessly undergoing various historical conflicts. It is not uncommon to spot these historical disputes to develop into territorial disputes. In this paper, three cases that best exemplify Northeast Asia's historical conflict are introduced.

\section{A. China's Northeast Project}

Under Chinese government's approval, Institute of Social Science has carried out the project that deals with China's Northeast region's history, geography, and ethnic race. This region is known to be once the territory of ancient Korea, so Chinese government's effort to merge the region's history as theirs has brought about Koreans' strong opposition. The project especially addresses the issue of Goguryeo - one of Korea's ancient nations - that contributed to the demise of China's Su dynasty. By defining Goguryeo not as an independent nation but as a subject state of China, the Chinese government aims to justify their rule over minority race residing in Northeast region and merge some parts of Korean history as Chinese.[8] That is why Chinese government obstructs North Korea's attempt to enter the Complex of the Goguryeo Toms as UNESCO World Heritage Site. Even though there has not been a direct military or diplomatic clash between China and Korea over China's Northeast Project, still this remains as one example of serious history distortion.

\section{B. Dokdo Island}

Another historical conflict occurs over a small island currently under Korean government's control, Dokdo. Both Koreans and Japanese have shown ebullient responses toward each other once the issue of Dokdo is raised. As a matter of fact, several Japanese politicians tried to visit Dokdo in 2011, which roused Koreans' antagonism and hostile attitude. Such territorial dispute over Dokdo is originated from Japanese Occupation. During the colonial period, Japan forcefully seized the Dokdo Island as a military base and stationed troops around the area. After Japan was defeated in the Second World War, Dokdo was returned to Korea and since then has been officially under Korean rule.[8] However, Japan still argues its right over Dokdo and even publishes history texts with distorted facts that glorify Japanese imperialism and conceal atrocities Japanese committed.

\section{Senkaku or Diaoyudao Islands}

The islands are situated east of mainland China and ruled by Japan. They once belonged to China but were given to Japan after China's defeat in Sino-Japanese war. The conflict began in earnest since 2010 when Japanese government captured Chinese fishermen in Senkaku Islands. Chinese government took decisive action and pressured Japanese government by declaring embargo on rare-earth metals that are crucial for Japan's manufacture industry. Japan did release fishermen, but the conflict continued. In fact, when Japan announced the nationalization of Senkaku Islands, Chinese - who originally had extreme historical antipathy towards Japan that previously conducted massacre and oppression of Chinese - were so enraged that they held huge scale demonstrations in front of Japan embassy.[8]

As seen from the cases, Northeast Asia nations' historical conflicts mostly stem from people's distrust of other nations, extreme nationalism, unsettled history of Japan's imperialism, and nations' distortion of history. The angst and hatred that people have - especially Korean and Chinese who suffered from Japanese brutal rule - work as the obstacle that tackles Northeast Asia's peace. Therefore, to alleviate animosity and to foster accurate understanding of the past, it is necessary to get insight from Ahn Jung-Geun's On Peace in East Asia.

\section{REALIZATION OF AHN's IDEAS IN RESOLVING HISTORICAL CONFLICTS}

As aforementioned, the underlying reasons of Northeast Asia's historical conflicts are people's antipathy from the past and governments' distortion of history. From Ahn Jung-Geun's on Peace in East Asia, we can draw his idea that can be adjusted to today's society: a sense of community and fellowship based on common cultural norm. This paper suggests mainly two ways how Korea, China, and Japan can form strong bond by sharing common historical and cultural foundation.

\section{A. Publishing Common History Textbook}

One of the reasons Japanese do not admit past atrocities is due to the distortion of their textbooks.[9] For instance, Japanese Occupation is portrayed as immense contribution to Korea's modernization and protection of Korea's security.[9] It expunged any contents about forceful draft of Koreans, 
sexual slaves, assassination of Korean empress, and other nefarious acts. Realizing that accurate and objective understanding of the past is fundamental, scholars from Korea, China, and Japan gathered to work on publishing common history textbooks, called History that opens the future [9]. Even thought the textbook is yet to be widely used and still has some points three nations' experts disagree on, it will work as a cornerstone that can bring Ahn's idea of "union" into reality.

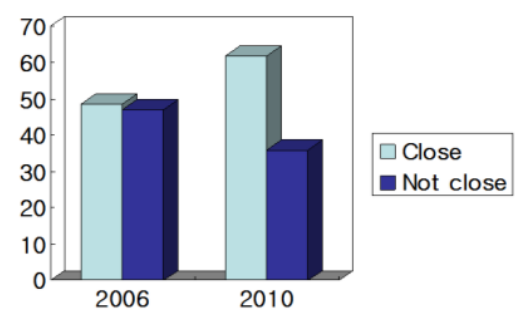

Fig. 2. Statistics showing the response.

\section{B. Fostering Common Culture though Hallyu}

Hallyu refers to the phenomenon of Korean pop culture gaining popularity in other nations. It includes dramas, songs, celebrities, movies, entertainments, etc. The increase in Japanese and Chinese people's preference for Korean pop culture indicates the possibility of Korean, Japanese, and Chinese sharing common cultural understanding. Spread of Hallyu propelled Japanese and Chinese to better understand Korean culture and perspectives. In fact, Japan's Yomiuri News conducted poll, which revealed that the number of Japanese and Chinese who start to learn Korean and the number of their visits increased. What is more significant is that Japanese hostility towards Koreans was assuaged as they started to embrace Hallyu. Following is the statistic that shows Japanese changing view towards Koreans; in 2006, $48.5 \%$ responded they feel close to Korea while $47.1 \%$ did not, but in $2010,61.8 \%$ responded they feel close while $36.0 \%$ did not.

Thus, it seems evident that further spreading Hallyu is another way to bring Korea, Japan, and China together and alleviate Northeast Asia historical conflicts.

\section{REFERENCES}

[1] J. G. Ahn, On Peace in East Asia, vol. 2, N.p.: Beom-U, 2010.

[2] J. G. Ahn, "Peaceful Asia: winning and recommended essays from the Ahn Jung-geun Essay Contest," Northeast Asian History Foundation, Seoul, Korea: Northeast Asian History Foundation, 2009.

[3] K. C. Seong, East Asia Hegemony War: Report of East Asia future strategy in context of 'road'. Seoul, Korea: Chari, 2011. Print.

[4] H. K. Seop, Multi-Dimensional Diplomacy: Response to a New Wave in East Asia, N.p.: n.p., n.d. Print.

[5] K. Kyung, "Examining Ahn Jung Geun and on peace in East Asia in context of East Asia: A road to open nationalism," Academy of Korean Studies, (n.d.): n. pag., July-Aug, 2013.

[6] T.-W. Choi, "On Peace in East Asia: its adoption in 21st century," Ahn Jung Geun and on Peace in East Asia, vol. 3, pp. 275-304, 2010.

[7] S. Yong. "Ahn Jung Geun's on peace in East Asia: historical significance," Ahn Jung Geun and on Peace in East Asia, vol. 3, pp. 51-78, 2010.

[8] S. H. Choi and Y. S. Kwon, 21st Century Northeast Asia Cultural Foundation, Seoul, Korea: Bupmunsa, 2004, July-Aug. 2013.

[9] S. J. Lee, Korea, China, Japan: Possibility of Publishing Common History Textbook, vol. 7, pp. 143-158, 2010.

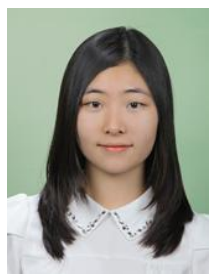

Yoo Song Lee was born in Seoul since then, she was raised in nearby Gyeong-Gi province. Currently, she attends Hankuk Academy of Foreign Studies, affiliated with Hankuk University of Foreign Studies. As a student in HAFS International Major, her academic interests are Political Science and International Relations, especially those of Northeast Asian nations. 